\title{
Producing Omega-3 Polyunsaturated Fatty Acids: A Review of Sustainable Sources and Future Trends for the EPA and DHA Market
}

\author{
Laura Oliver ${ }^{1, *}$, Thomas Dietrich ${ }^{1}$, Izaskun Marañón ${ }^{1}{ }^{1}$, Maria Carmen Villarán ${ }^{1}$ \\ and Ramón J. Barrio ${ }^{2}$ \\ 1 Health and Food Area, Health Division, TECNALIA, Basque Research and Technology Alliance (BRTA), \\ Parque Tecnológico de Álava, c/Leonardo Da Vinci no. 11, 01510 Miñano, Spain; \\ thomas.dietrich@tecnalia.com (T.D.); izaskun.maranon@tecnalia.com (I.M.); \\ mcarmen.villaran@tecnalia.com (M.C.V.) \\ 2 Department of Analytical Chemistry, Faculty of Pharmacy, University of the Basque Country (UPV/EHU), \\ Paseo de la Universidad 7, 01006 Vitoria-Gasteiz, Spain; r.barrio@ehu.es \\ * Correspondence: laura.oliver@tecnalia.com
}

Received: 16 November 2020; Accepted: 14 December 2020; Published: 16 December 2020

\begin{abstract}
Omega-3 polyunsaturated fatty acids (Omega-3 PUFA) are recognized as being essential compounds for human nutrition and health. The human body generates only low levels of Omega-3 PUFA. Conventional sources of Omega-3 PUFA are from marine origin. However, the global growth of population combined with a better consumer understanding about healthy nutrition leads to the fact that traditional sources are exhausted and therefore not enough to satisfy the demand of Omega-3 PUFA for human diet as well as aquaculture. Microalgae cultivated under heterotrophic conditions is increasingly recognized as a suitable technology for the production of the Omega-3 PUFA. The high cost of using glucose as main carbon source for cultivation is the main challenge to establish economical feasible production processes. The latest relevant studies provide alternative pathways for Omega-3 PUFA production. As preliminary results show, volatile fatty acids (VFA) recovered from waste stream could be a good alternative to the use of glucose as carbon source in microalgae cultivation. The purpose of this paper is to highlight the actual situation of Omega-3 PUFA production, sources and market request to provide a summary on sustainable sources that are being investigated as well as present and future market trends in Omega-3 market.
\end{abstract}

Keywords: heterotrophic microalgae; sustainable sources; volatile fatty acid; docosahexaenoic acid; market trends; nutrition

\section{Introduction}

Omega-3 PUFA are recognized as being essential compounds for human nutrition and health. Epidemiological studies on Greenland Inuit in the 1970s and subsequent human studies have established an inverse relationship between the ingestion of Omega-3 PUFA, blood levels of them and mortality associated with cardiovascular disease (CVD) [1-4]. Subsequently, numerous studies have been carried out regarding the functionality of Omega-3 PUFA against numerous diseases, such as coronary heart disease, thrombosis, macular degeneration, dementia, diabetes, allergy, asthma, osteoporosis, some types of cancer, etc. [5-8]. Even in the context of the recent COVID-19 pandemic, Omega-3 PUFA are suggested in therapeutic strategies to prevent the so-called "cytokine storm" and they play an important role as potential adjuvant therapy in cardiovascular complications associated to COVID-19 [9-12]. 
Omega-3 PUFA participate in metabolic pathways which activate the resolving phase of inflammation. Eicosapentaenoic acid (EPA) and Docosahexaenoic acid (DHA) are the main precursors to produce specialized proresolving mediators (SPMs) known as resolvins, maresins and protectins, inhibiting the synthesis of proinflammatory cytokines $[13,14]$. In contrast, Omega- 6 fatty acids participate in metabolic pathways which support the formation of proinflammatory metabolites [15]. Arachidonic acid (ARA), the main precursor for this synthesis, leads to the production of cellular mediators promoting inflammation, like leukotrienes and prostaglandins [9].

Among all, only alpha-linolenic acid (ALA) and linoleic acid (LA) are strictly essential fatty acids for humans because they are the precursors of the other members of families Omega- 3 and Omega- 6 respectively [16]. It is not known exactly what the optimal ratio between Omega-3/Omega-6 is, but several sources suggest that our ancestors survived on a diet that contained an Omega-6/Omega-3 ratio of $1-4: 1$, in contrast to the average diet of the current western population, where this ratio amounts to more than 15:1 [17-19]. This means that the low contribution of Omega-3 acids, together with an excess of Omega- 6 acids in tissues can be one of the causes of the high prevalence of certain diseases.

Generally, the human body generates only low levels of Omega-3 PUFA. It is estimated that only $8-20 \%$ of a dose of ingested ALA is converted into EPA and $0.5-9 \%$ into DHA [20]. Therefore, Omega-3 PUFA and specially long-chain PUFA as DHA are recommended to be acquired through diet [21-24]. Conventional sources of Omega-3 PUFA are from marine origin, primarily fish and crustaceans, which have been a regular part of the diet since prehistory [21,25].

The greater knowledge about the effect of the diet on health has led in recent years to an increased demand for food and supplements able to provide health promoting compounds. Growing global population will therefore require larger food production in general as well as production of fish and seafood. Fish production in aquaculture offers one alternative, which unfortunately led the growing demand for fish meal and oil as feedstock for aquaculture to significant price increases and shortages of these crucial base materials [26].

Therefore, it is crucial to investigate new sources of Omega-3 PUFA to be used for fish farming but also to respond to the growing demand of these health promoting fatty acids by the food, nutraceutical and pharmaceutical industry. One promising alternative to fish oil represents microalgae as they are the primary producers of these fatty acids in marine food webs [27-29]. Among other high value-added products, some specific microalgae produce long-chain polyunsaturated fatty acids, such as EPA and DHA [30]. For this reason, numerous studies are being carried out to achieve a sustainable production of microalgae, with the aim to increase the production of Omega-3 PUFA [31-33].

\section{Future Trends and Perspectives of EPA and DHA Market}

Disruptive changes are determining the course of this century around the world: innovative technologies, political events, demographic changes, globalization and climate change drive the most of disruptions occurring nowadays. The combination of these driving forces is promoting relevant trends related with food and health, as well as the relationship between them. In this context, Omega-3 based products have an opportunity to increase their market share, because there is an increasing number of scientific evidences about the effectiveness of these compounds to improve human health and wellness.

The global Omega-3 market size was valued at USD 2.49 billion in 2019 and is expected to expand at a CAGR of 7\% over the period 2020-2027. Nowadays, the most important application sector is related to Supplements and Functional Foods and it is expected a sustained growth over the forecast period. However, the proved influence of Omega-3 PUFA in several chronical diseases will promote the penetration of these products in the pharmaceutical sector, as an active pharmaceutical ingredient [34]

Relevant market reports such as the report from Grand View Research or from Markets and Markets agree on the EPA and DHA segment is projected to grow in terms on revenue due to their application on dietary supplements, functional foods or clinical nutrition [35]. As EPA and DHA are commonly found in marine oils, and plant oils are the major source of ALA, Marine segment is 
expected to be the largest and fastest growing segment by source. However, Markets and Markets point out an important challenge related to the rising prices of fish oils due factors such as the restrictions on fishing in high sea areas or the increasing cost of aquaculture. However, in relation to this challenge, an opportunity arises based on the search for innovative sources of EPA and DHA that are most cost-effective, such as heterotrophic microalgae.

One of the driving forces for the expected growing of Omega-3 market is related with the demographic changes and their impact in social and health spending. According to WHO, the ageing of the world's populations is the result of the continued decline in fertility rates and increased life expectancy. This demographic change has resulted in increasing numbers and proportions of people who are over 60. In July 2019, Eurostat updated the population projections in the period from 2018 to 2100: the EU-27's population is projected to increase to a peak of 449.1 million around 2030 and thereafter gradually decline to 416.9 million by 2100 [36]. Moreover, it is interesting to note the evolution of the population distribution depending on the range of ages, because the population is projected to continue to age as well as the progressive ageing of the older population itself, because the very old population segment is projected to grow at a faster rate than other age segments.

Promoted by relevant entities such as the WHO, Healthy Ageing concept means "the process of developing and maintaining the functional ability that enables wellbeing in older age". To create the opportunity for every person to live a long and healthy life, correct nutrition must be addressed throughout life. According with the global demographic projections, the demand for specific ingredients able to contribute to healthy ageing will be increased. The American Heart Association (AHA) projected in 2016 that by $2035,45.1 \%$ of the US population would have some form of CVD with an expected cost around \$1.1 trillion in that year: the evolution of total cost estimated between 2015 and 2035 is to remain relatively stable from 18- to-44-year-olds, increase slightly from 45- to 64-years-olds and increase sharply for 65- to 79-year-olds and adults aged $\geq 80$ years [37]. Regarding the historic data form US and Europe, a similar evolution is expected for European population: the prevalence and costs related with heart diseases are projected to increase substantially if cardiovascular disease incidence is not reduced. Governments are implementing different strategies conducted to reduce the risk factors (to reduce tobacco, sugar or fat consumption) but also to promote a healthy and personalized nutrition and supplementation, because according with the $\mathrm{WHO}, 80 \%$ of premature heart disease and stroke is preventable.

In this context, since the effectiveness of Omega -3 PUFA against cardiovascular diseases has been shown in numerous studies, international authoritative bodies-such as World Health Organization (WHO), European Food Safety Authority (EFSA) or Institute of Medicine from USA-as well as expert scientific organizations-such as American Heart Association, European Academy of Nutritional Sciences or International Society for the Study of Fatty Acids and Lipids (ISSFAL)—and industrial partners—such as The Global Organization for EPA and DHA Omega-3s (GOED)—recommend and promote the Omega -3 PUFA regular intake [38,39].

The support of such relevant, recognized and reliable institutions promoting the daily intake of omega-3 PUFAs drives the expected increase in the market for supplements and functional foods, as well as pharmaceuticals. However, there is a restraint for the market of Omega-3 due to the absence of an official recommended dose. For example, while Food and Agriculture Organization (FAO) of the United Nations and WHO recommends a daily intake of $250 \mathrm{mg}$ of EPA and DHA per adult to give optimal protection against diseases, ISSFAL and GOED recommends at least $500 \mathrm{mg} /$ day of EPA and DHA for general adult population for cardiovascular health [40-42]. More studies are being conducted in order to standardize a daily recommended intake for adult population.

Another relevant opportunity for the Omega -3 PUFA comes from the increasing number of ocular problems. Climate change is related with changes in stratospheric ozone layer and alterations of solar ultraviolet radiation. In turn, these factors are related to the oxidative stress, including an increasing oxidative damage on eyes and the macular degeneration [43,44]. However, also the emergence of innovative technologies related with the use of a large number of blue light screens in our 
daily lives is accelerating the appearance of vision problems in the all ages of the population $[45,46]$. Medical evidence points the DHA support for cells of the retina as a crucial ingredient for healthy vision [47].

Even if the opportunity of Omega-3 PUFA ingredients could be projected as a growing market within the market of functional ingredients, there are other social and environmental trends that should be considered. The increase in the demand of Omega-3 PUFA to assure the supply is not the only reason to find nonconventional sources different of fish products. A relevant trend influencing the introduction of the Omega-3 PUFA ingredient to the food and beverage market is the rise of animal-free ingredients. In this context, the development of products not based on fish-oils is required not only to satisfy the increasing demand but also to tackle the new consumer trends.

\section{Traditional Sources for Omega-3 Polyunsaturated Fatty Acid Consumption}

Normally, seafood is the best way to consume health-promoting Omega-3 PUFA. Fish species considered in general having a high amount of Omega- fatty acids include beside other salmon, tuna, mackerel, sardines, ancho vies, herring or pollock. In order to achieve $250 \mathrm{mg}$ of EPA and DHA per day, recommendations suggest consuming 2-3 servings of fatty fish per week [48-50]. These recommendations require a more detailed analysis as content of Omega-3 PUFA fatty acids depend on several factors such as specie, wild or farmed fish or time and zone of capture. Wild captured fish should be considered as nutritional reference and the nutritional values of farmed fish should comply with them. Due to overfishing in recent decades tightly regulated catch quotas for fish capture were implemented to protect the fishing grounds. Therefore, the quantity of wild fish available for human consumption has been nearly constant in recent years (Figure 1).

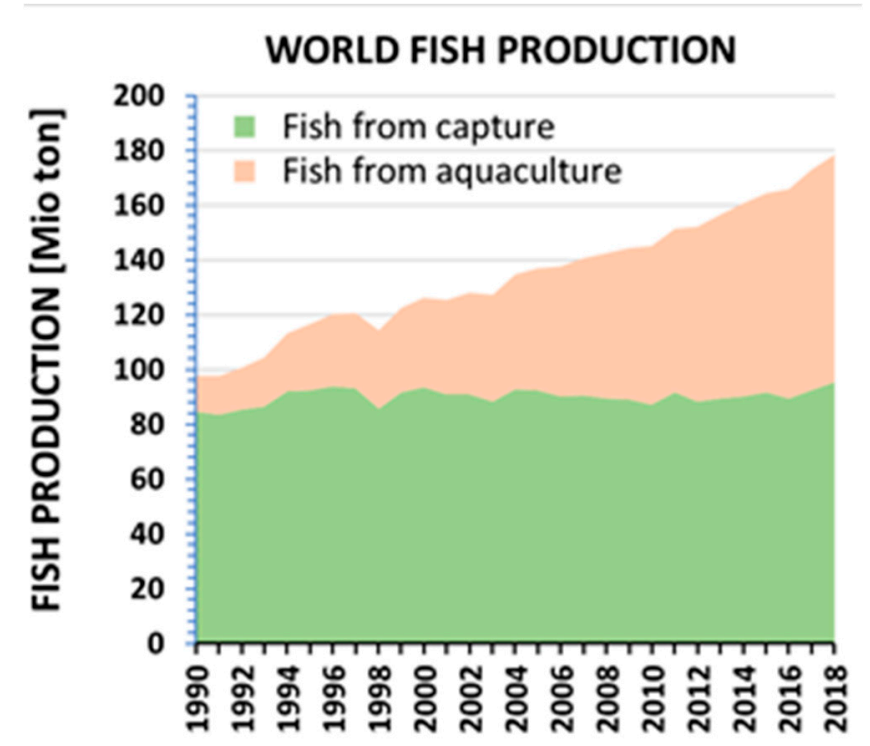

Figure 1. World Fish Production from 1990 to 2018-Capture Fishery vs. Fish production from Aquaculture obtained from Dataset: OECD-FAO Agricultural Outlook 2019-2028, World production [51,52].

On the other hand, the demand for fish products is increasing due to growing population and known health promoting benefits. Therefore, fish farming in aquaculture has been established as an alternative. The main ingredients for fish production in aquaculture are fish meal and fish oil obtained from capture fishery. The significant increase of aquaculture and demand for marine ingredients has led to an enormous pressure for these kinds of raw materials. This can be seen in Figure 2. Fish oil and fish meal production are constant or decreasing, while prices increasing more than $100 \%$ in the last 20 years aligned with increased aquaculture production. To reduce production costs, aquaculture 
industry is looking for alternative protein and oil sources to be used as raw material for fish feed production. This has significant influence on the nutritional value of the final product. Normally Atlantic salmon, an oily fish, is a rich source of the health promoting long-chain Omega-3 PUFA, EPA, and DHA acids. However, fish is not the primary producer of long chain Omega-3 PUFA and people need to assimilate EPA and DHA through their diets. Fish cultivated in aquaculture needs to be provided the beneficial Omega-3 PUFA through their feed in terms of, for example, fish oil.

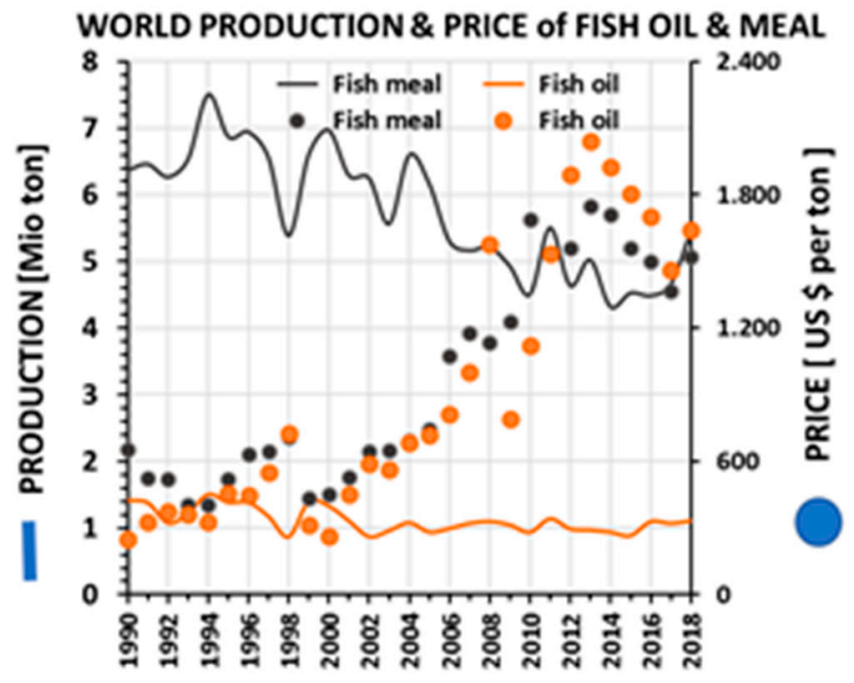

Figure 2. World Production and Price from 1990-2018 for Fish oil and Fish meal obtained from Dataset: OECD-FAO Agricultural Outlook 2019-2028 [51], World production [52] and world prices [53].

Unfortunately, due to the replacement of fishmeal and fish oil in farmed salmon diets with alternatives of terrestrial origin, a significant decrease in EPA and DHA levels between 2006 and 2015 were detected. Already in 2011, Andrew Jackson, Technical Director of International Fishmeal and Fish Oil Organization stated that salmon have been sold on their health-giving properties and this will be increasingly challenged as the final level of EPA/DHA in the fillets will be decreased [54]. Therefore, the findings of Sprague et al. highlight clearly the global shortfall of EPA and DHA and the implications for the human consumer looking for healthy aquaculture seafood [55]. For these reasons, the industry has been looking for alternative omega-3 supplies to fill the gap between the demand and the supply of EPA and DHA, allowing a sustainable growth of the aquaculture industry.

The Global Salmon Initiative [56] has invited commercial organizations to supply its members with up to 200,000 tons annually of novel omega-3 rich oils to support the sustainable use of marine oils in aquafeeds These new alternatives are meant to ensure continued growth of the industry without compromising the performance and the health of the fish or the nutritional quality of the final product [57].

A recent review [27] has focused on the use of new algal biomass for different aquatic species, especially salmonids and shrimp [58,59] or algal oil omega-3 sources [60-64]. The review shows that these new omega-3 sources can be used as new ingredients in the formulation of aquafeeds with no negative impacts on fish growth, feed efficiency or health. Limited availability of fish oils (FO), rich in Omega-3 PUFA, is a major constraint for further growth of the aquaculture industry. Long-chain Omega-3 rich oils from crops GM with algal genes are promising new sources for the industry. There are studies of a newly developed n-3 canola oil (DHA-CA) in diets of Atlantic salmon. The DHA-CA oil has higher proportions of the FA and DHA than conventional plant oils and the study shows that the DHA-CA can effectively replace fish oil as a new safe dietary source of DHA for Atlantic salmon during the sensitive fingerling life-stage [64].

Global warming is another key point to be considered regarding DHA availability for the future. The production of DHA by algae cells is increased when the temperature of aquatic ecosystem is 
lower [65-67]. For that reason, some studies suggest that the global warming could affect the production of DHA and consequently its availability for human consumption in the future [68]. Colombo et al. [69] studied different scenarios for DHA availability in the next 100 years, taking in consideration the effect of global warming on DHA production by algae. The prediction model suggested that in the worst scenario only $4 \%$ of the global population could have access to recommended DHA intake. Simply stated, there is not enough Omega-3 PUFA available from the traditional sources to satisfy human nutritional requirements and aquaculture. Therefore, the focus is changing towards the primary producers.

There are studies on the efficiency of nonfish meal or nonfish oil diets for the development of different marine aquaculture fish. In these studies, fish meal and fish oil were replaced by algae meal (Schizochytrium sp. powder) and plant proteins. The authors described the possibility to develop a microalgae diet as a lipid source of Omega-3 fatty acid on marine fish [70]. Marine microalgae represent a promising possibility to produce Omega-3 PUFA. Many photosynthetic microalgae are known to synthesize high levels of EPA. Among others Nannochloropsis, Monodus subterraneus, Phaeodactylum tricornutum, Odontella aurita and Pophyridium cruentum are described [71,72]. Ma et al. reached EPA levels of $12.74 \pm 1.84 \%$ in Nannochloropsis salina CCMP1176 and $10.93 \pm 1.84 \%$ in Nannochloropsis oceanica CCMP537 on total fatty acids [73], and Ryckebosch et.alobtained EPA levels of $22.4 \pm 1.7 \%$ up to $31.4 \pm 1.7 \%$ in Phaeodactylum tricornutum [74]. Currently, several companies use photoautrophic conditions to produce EPA-rich microalgae biomass. Shenzhen Qianhai Xiaozao Technology Co., Ltd. (China) produces EPA rich lipid extract from Nannochloropsis salina. Other examples are Arizona Algae Products, LLC (US) or Simris Alg AB (Sweden).

Recent advances have been made in deciphering the genomes and transcriptomes of multiple high- value algal species and their metabolic pathways toward carotenoid, lipid, and PUFA biosynthesis [75-77]. With recent progress in microalgae transformation and genetic engineering, it is now possible to increase production efficiencies for high-value products, bulk biomass and biofuels in microalgae by metabolic engineering [78]. However, the development of efficient large-scale microalgal cultivation systems is essential to produce microalgae derived Omega-3 fatty acids. In general, microalgal cultivation systems can be broadly divided into photoautotrophic and heterotrophic systems. Photoautotrophic production depends on enough light entry and carbon dioxide, while heterotrophic systems require organic substrates as carbon and energy source. Heterotrophic cultivation systems are considered superior since light, the growth-limiting factor, is eliminated.

\section{Heterotrophic Microalgae for Omega-3 Polyunsaturated Fatty Acids Production}

Studies have been conducted for a long time on the feasibility of using microalgae as sources of Omega-3 fatty Acids [79]. Diatoms are a major group of high omega 3-fatty acid producing algae that play a key role in global climate change and ecosystem function. In a recent review, the possibilities of Phaeodactylum tricornutum microalgae as a rich source of omega-3 oil were evaluated [80]. Phaeodactylum tricornutum is one of only two diatoms whose genomes have been completely sequenced, leading to metabolic engineering of high EPA producing strains. Based on its rapid growth, high lipid content and omega-3 PUFA, P. tricornutum exhibits a large commercial potential.

Food and pharmaceutical quality production can be enhanced both by the degree of process control and by the sterility achieved through a fermentation process, when compared to outdoor solar pond production. The capacity of certain species of microalgae to grow under heterotrophic conditions, with no light and relatively small space requirement, implies that they can be cultivated around the world independently of the climate, converting them in a promising alternative to produce Omega-3 PUFA. Microalgal-based heterotrophic production. systems can exhibit omega-3 fatty acid productivities 2-3 orders of magnitude greater than those of autotrophic production. Additionally, omega-3 PUFA productivities reported for the microalgal fermentation systems are 1-2 orders of magnitude greater than productivities reported for fungal or bacterial systems [81]. 
Two main families could be considered as main Omega-3 PUFA producers under heterotrophic conditions: thraustochytriacea and Crypthecodiniacea family. A great number of reports can be found in the literature explaining their growth under heterotrophic conditions. In particular, schyzochitrium and ulkenia from thraustochytriacea and crypthecodinium from Crypthecodiniacea present the higher amount of Omega-3 PUFA, especially DHA [82]. Gupta et al. reported that Thraustrochytrium aureum 28210 can reach $48.3-58.2 \%$ of DHA of total fatty acids [83]. Lee Chang et al. reported results of $41-75 \%$ of DHA of total fatty acids for Thraustrochytrium aureum 38304 strain -and 5-13\% of DHA for ulkenia [84]. In a recent report, the main PUFA producer's growth under heterotrophic conditions were reviewed by Chalima et al. [85].

To grow under heterotrophic conditions, some basic requirements of macronutrients are needed. Carbon, nitrogen and phosphorous are the most relevant macronutrients. Generally, glucose is used as carbon source, yeast extract or ammonium is used as nitrogen source and phosphate is used as phosphorous source. Glucose may lead around $80 \%$ of total cost of heterotrophic cultivation, and therefore is the main drawback from an economical point of view to produce DHA under heterotrophic conditions [86]. Although heterotrophic culture of microalgae for EPA and DHA production is being carried out at commercial scale by several companies such as Fermentalg, DSM or XiaoZao Tech, the high economical cost and environmental impact of using glucose as carbon source implies that the production of high-quality Omega- 3 PUFA might be carried out in cheaper ways following the identification of cheaper carbon source.

\section{Alternative Carbon Sources for Sustainable EPA/DHA Production}

Glycerol, acetate, prehydrolyzed whey permeate, forest biomass or food waste hydrolysates were described by different authors as alternative carbon source for the heterotrophic culture of C. pyrenoidosa, A. protothecoides, S. mangrovei or S. limacinum [87-89]. In most cases, reports were focused on biodiesel production. Only in recent years some studies related to the use of alternative carbon sources Omega-3 PUFA production processes are being published. In this context, Schizochytrium specie growing on alternative carbon source is probably one of the best microalgae studied for Omega-3 PUFA production as the number of reports were described in literature.

Glycerol and fructose were compared to glucose in DHA production, by Wang et.al. [90]. Some authors described the use of sugarcane waste as alternative carbon source [91-93]. Nguyen et al. reported the cultivation of Schizochytrium sp. with sugarcane bagasse hydrolysate concluding that, both biomass and lipid content was higher using sugarcane bagasse (10.45 g/L biomass, $45.5 \%$ lipid content) after $72 \mathrm{~h}$ of cultivation hydrolysate since not only glucose is used but also xylose and other carbohydrates are participating in metabolic pathways.

Cane molasses, as alternative carbon source for the growth of Schizochytrium sp. was investigated by Yin et al., but they conclude that cane molasses cannot be used as sole carbon source due to the presence of some metal ions and colloid substance. These substances might be toxic for the cells [94]. Although a pretreatment can be applied before their use to remove these substances, e.g., sulfuric acid or tricalcium phosphate, these substances cannot be completely removed from the substrate. Therefore, a two-stage cultivation strategy is investigated by the authors. In a first stage, glucose is used as carbon source to enhance the production of biomass. After nitrogen consumption (under stress conditions, the accumulation of DHA-rich lipid is enhanced), a second stage with cane molasses pretreated, as carbon source, is performed to increase the DHA yield. Not only can Schizochytrium be cultivated utilizing alternative carbon sources, other microalgae species (Scenedesmus acutus, Chlorella protothecoides) have been cultivated in a medium containing sugarcane bagasse with promising results, suggesting that sugarcane bagasse could be an alternative source to glucose in heterotrophic cultivation $[33,95,96]$.

Lignocellulosic biomass was recently investigated by Karnaouri et al. [97]. The enzymatic hydrolysate was applied as nutrient for Crypthecodinium cohnii growth with successful results, reaching up to $43.5 \%$ of DHA. The ability of Crypthecodinium cohnii strain to grow on galacturonic acid obtained 
from the valorization of exhausted olive pomace suggests that galacturonic acid could represent a good candidate to be investigated in biotechnological applications [98].

Some authors described a combination of nutrients as alternative source. Birch wood hydrolysate and dairy effluents were used by Lage et al. for producing lipids in Chlorella sorokiniana, Chlorella saccharophila, Chlorella vulgaris, and Coelastrella sp., strain cultures. However, all of them have been studied regarding lipids in general and not DHA in particular [99]. Among all the alternatives investigated, the use of waste derived volatile fatty acids (VFA) as carbon source shows an immense potential for the production of Omega-3 PUFA.

The term volatile fatty acids (VFA) is referred to as short-chain fatty acids, with a similar chemical structure, consisting of two to six carbon atoms. The synthesis of VFA is usually carried out through petrochemical processes with the resulting hazardous environmental impact. VFA can be used for diverse applications by itself and as a carbon source for added value fermentation approaches such as hydrogen or electricity generation [100]. Due to the increasing demand of VFA and the high cost and environmental impact associated with its production, alternative processes are investigated to achieve a low cost VFA production.

The use of different types of waste streams to produce VFA via dark fermentation offer a promising approach to reduce economic and environmental impact [100]. Dark fermentation process can be compared to anaerobic digestion. While anaerobic digestion (AD) leads to biogas/methane, dark fermentation to produce volatile fatty acids is inhibiting the last stage-methanogenesis of AD, as it is graphically described in Figure 3 [101]. Different types of substrates such as Vegetable, Garden and Fruit waste (VGF), organic fraction from municipal solid waste (MSW), food waste or wastewater treatment plant (WWTP) sludge can be used for VFA production. According to the CEN Workshop Agreement CWA 17484:2020, the VFA production potential can be estimated as follows [102]:

- Food waste $627 \mathrm{~g}$ COD (Chemical oxygen demand)/kg organic matter

- VGF waste $448 \mathrm{~g} \mathrm{COD} / \mathrm{kg}$ organic matter

- Organic fraction MSW $384 \mathrm{~g}$ COD/kg organic matter

- WWTP sludge before AD $179 \mathrm{~g} \mathrm{COD} / \mathrm{kg}$ organic matter

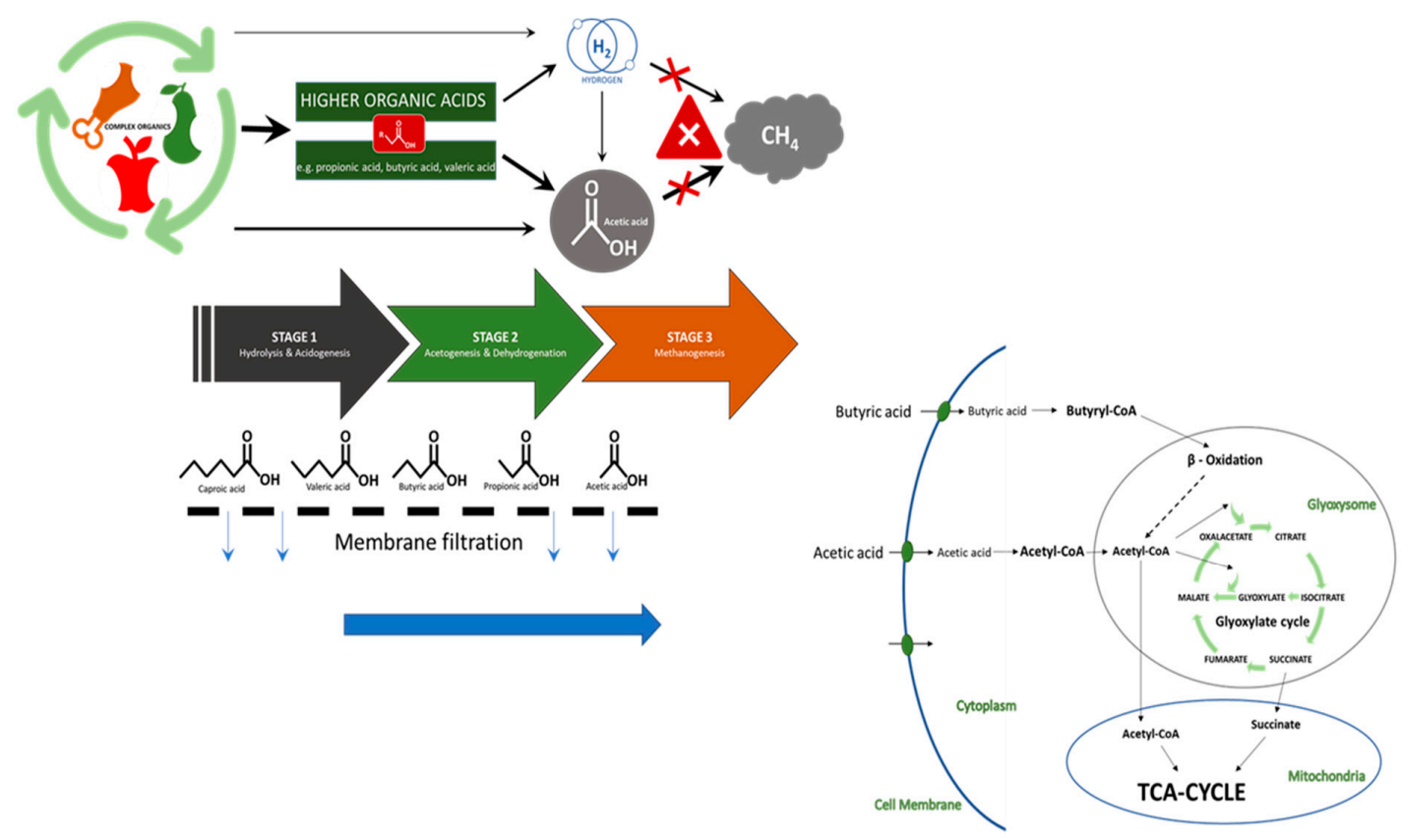

Figure 3. Production of volatile fatty acids (VFA) via dark fermentation and metabolic pathways in heterotrophic microalgae. 
VFA can be recovered, cleaned and concentrated from dark fermentation broth by using membrane filtration from ultrafiltration and nanofiltration to reverse osmosis. The cleaned and concentrated VFA can be used as carbon source for DHA production with microalgae $[97,103]$. Chalima et al. reviewed in detail the production of VFA from different waste streams, such as sludge, wastewaters from agricultural industries and food waste and wastewater from paper industry and the potential of these VFA for microalga fermentation [104]. Scenedesmus, Chlorella. Chlamydomonas and Crypthecodinium cohnii can be growth on VFA [104].

In comparison to other alternative sources in which a pretreatment is required (breaking down the carbon source to simple sugar), VFA offer the advantage of being able to be used directly by microalgae to produce PUFA in an economic manner under heterotrophic conditions $[104,105]$. As shown in Figure 3, microalgae use short-chain fatty acids to produce long-chain fatty acids and therefore VFA provide microalgae with a carbon chain ready to be elongated to PUFA. Turon et al. reported several studies regarding the potential of dark effluents as substrate $[32,82,106]$ and Patel et al. also reported the potential of Auranthiochytrium sp. to grow using VFA as carbon source $[107,108]$.

The interest of VFA has been increasing in recent years, confirmed by numerous reports that are being published [32,105,108,109].

Currently studies that focused on the use of sustainable carbon sources to produce Omega-3 PUFA are summarized in Table 1.

Table 1. Carbon sources to produce microalgal oil and Omega-3 PUFA.

\begin{tabular}{cccc}
\hline Microalgae Specie & Carbon Source & Products & Reference \\
\hline Schizochytrium sp. & Glycerol, fructose & DHA & {$[90]$} \\
Schizochytrium sp. & Sugarcane bagasse & Lipids, biomass & {$[92,93]$} \\
Schizochytrium sp. & Cane molasses & Microalgal oil & {$[94]$} \\
Schizochytrium mangrovei & Food waste hydrolysate & Microalgal oil & {$[88]$} \\
Chlorella pyrenoidosa & Food waste hydrolysate & Microalgal oil & {$[88]$} \\
Chlorella pyrenoidosa & Food waste hydrolysate & Microalgal oil & {$[88]$} \\
Aurantiochytrium sp. T66 & Forest biomass hydrolysates & DHA & {$[107]$} \\
Crypthecodinium cohnii & Lignocellulosic biomass & DHA & {$[97]$} \\
Crypthecodinium cohnii & Galacturonic acid & DHA & {$[98]$} \\
Crypthecodinium cohnii. & VFA mix from organic waste & DHA & {$[104]$} \\
Chlorella pyrenoidosa & VFA mix from organic waste & Microalgal oil & {$[104]$} \\
Scenedesmus sp. & VFA mix from organic waste & Microalgal oil & {$[104]$} \\
Crypthecodinium cohnii & Dark fermentation effluent & DHA & {$[109]$} \\
Aurantiochytrium sp. T66 & VFA & DHA & {$[107,108]$} \\
\hline
\end{tabular}

\section{Conclusions}

The main purpose of this paper was to highlight the limitations involved in the Omega -3 PUFA actual production, their projected demand/market perspectives and the possibilities offered by heterotrophic microalgae to supply them. Microalgal-based heterotrophic production systems can exhibit omega-3 fatty acid productivities several orders of magnitude greater than those of autotrophic production. The main challenge in the use of heterotrophic microalgae to produce Omega -3 PUFA is associated with the high cost and environmental impact for the carbon sources to be used. Generally, glucose is used as carbon source, and it may lead to around $80 \%$ of total cost of heterotrophic cultivation This review focused on compiling studies that are currently being performed to develop economic feasible processes for EPA and DHA production. Carbon sources from renewable side (food waste hydrolysates, lignocellulosic biomass, sugarcane waste, cane molasses) could be a good alternative as latest publications reveal. Finally, different types of substrates such as vegetable, garden and fruit waste, organic fraction from municipal solid waste, food waste or wastewater treatment plant sludge can be used for volatile fatty acids (VFA) production. The cleaned and concentrated VFA can be used as carbon source for DHA production with microalgae. 
Author Contributions: Conceptualization, L.O., M.C.V. and R.J.B., writing-original draft preparation, L.O., T.D. and I.M.; writing-review and editing, M.C.V. and R.J.B. All authors have read and agreed to the published version of the manuscript.

Funding: The authors would like to thank the European project VOLATILE. The project has received funding from the European Union's Horizon 2020 research and innovation programme under grant agreement No 720777.

Conflicts of Interest: The authors declare no conflict of interest.

\section{References}

1. Jump, D.B.; Depner, C.M.; Tripathy, S. Omega-3 fatty acid supplementation and cardiovascular disease. J. Lipid Res. 2012, 53, 2525-2545. [CrossRef] [PubMed]

2. Darwesh, A.M.; Sosnowski, D.K.; Lee, T.Y.; Keshavarz-Bahaghighat, H.; Seubert, J.M. Insights into the cardioprotective properties of n-3 PUFAs against ischemic heart disease via modulation of the innate immune system. Chem. Interact. 2019, 308, 20-44. [CrossRef] [PubMed]

3. Endo, J.; Arita, M. Cardioprotective mechanism of omega-3 polyunsaturated fatty acids. J. Cardiol. 2016, 67, 22-27. [CrossRef] [PubMed]

4. Hirafuji, M.; Machida, T.; Hamaue, N.; Minami, M. Cardiovascular protective effects of n-3 polyunsaturated fatty acids with special emphasis on docosahexaenoic acid. J. Pharmacol. Sci. 2003, 92, 308-316. [CrossRef] [PubMed]

5. Lands, W. Historical perspectives on the impact of n-3 and n-6 nutrients on health. Prog. Lipid Res. 2014, 55, 17-29. [CrossRef]

6. Saidane, O.; Semerano, L.; Sellam, J. Could omega-3 fatty acids prevent rheumatoid arthritis? Jt. Bone Spine 2019, 86, 9-12. [CrossRef]

7. Ye, Y.; Pang, Z.; Chen, W.; Ju, S.; Zhou, C. The epidemiology and risk factors of inflammatory bowel disease. Int. J. Clin. Exp. Med. 2015, 8, 22529-22542.

8. Schunck, W.-H.; Konkel, A.; Fischer, R.; Weylandt, K.-H. Therapeutic potential of omega-3 fatty acid-derived epoxyeicosanoids in cardiovascular and inflammatory diseases. Pharmacol. Ther. 2018, 183, 177-204. [CrossRef]

9. Weill, P.; Plissonneau, C.; Legrand, P.; Rioux, V.; Thibault, R. May omega-3 fatty acid dietary supplementation help reduce severe complications in Covid-19 patients? Biochimie 2020, 179, 275-280. [CrossRef]

10. Szabó, Z.; Marosvölgyi, T.; Szabó, É.; Bai, P.; Figler, M.; Verzár, Z. The potential beneficial effect of EPA and DHA supplementation managing cytokine storm in Coronavirus disease. Front. Physiol. 2020, 11, 752. [CrossRef]

11. Darwesh, A.M.; Bassiouni, W.; Sosnowski, D.K.; Seubert, J.M. Can N-3 polyunsaturated fatty acids be considered a potential adjuvant therapy for COVID-19-associated cardiovascular complications? Pharmacol. Ther. 2020, in press, 107703. [CrossRef]

12. Hammock, B.D.; Wang, W.; Gilligan, M.M.; Panigrahy, D. Eicosanoids: The overlooked storm in Coronavirus disease 2019 (COVID-19)? Am. J. Pathol. 2020, 190, 1782-1788. [CrossRef] [PubMed]

13. Calder, P.C. Omega-3 polyunsaturated fatty acids and inflammatory processes: Nutrition or pharmacology? Br. J. Clin. Pharmacol. 2013, 75, 645-662. [CrossRef] [PubMed]

14. Ortega-Gómez, A.; Perretti, M.; Soehnlein, O. Resolution of inflammation: An integrated view. EMBO Mol. Med. 2013, 5, 661-674. [CrossRef] [PubMed]

15. Yates, C.M.; Calder, P.C.; Rainger, G.E. Pharmacology and therapeutics of omega-3 polyunsaturated fatty acids in chronic inflammatory disease. Pharmacol. Ther. 2014, 141, 272-282. [CrossRef] [PubMed]

16. Punia, S.; Sandhu, K.S.; Siroha, A.K.; Dhull, S.B. Omega 3-metabolism, absorption, bioavailability and health benefits-A review. PharmaNutrition 2019, 10, 100162. [CrossRef]

17. Molendi-Coste, O.; Legry, V.; Leclercq, I.A. Why and how meet n-3 PUFA dietary recommendations? Gastroenterol. Res. Pr. 2010, 2011,1-11. [CrossRef]

18. Patterson, E.; Wall, R.; Fitzgerald, G.F.; Ross, R.P.; Stanton, C. Health implications of high dietary omega-6 polyunsaturated fatty acids. J. Nutr. Metab. 2012, 2012, 1-16. [CrossRef]

19. Simopoulos, A.P. The importance of the ratio of omega-6/omega-3 essential fatty acids. Biomed. Pharmacother. 2002, 56, 365-379. [CrossRef] 
20. Weylandt, K.H.; Serini, S.; Chen, Y.Q.; Su, H.-M.; Lim, K.; Cittadini, A.; Calviello, G. Omega-3 polyunsaturated fatty acids: The way forward in times of mixed evidence. BioMed Res. Int. 2015, 2015, 1-24. [CrossRef]

21. Saini, R.K.; Hur, S.J. Omega-3 and omega-6 polyunsaturated fatty acids: Dietary sources, metabolism, and significance-A review. Life Sci. 2018, 203, 255-267. [CrossRef] [PubMed]

22. Calder, P.C. Eicosapentaenoic and docosahexaenoic acid derived specialised pro-resolving mediators: Concentrations in humans and the effects of age, sex, disease and increased omega- 3 fatty acid intake. Biochimie 2020, 178, 105-123. [CrossRef]

23. Troesch, B.; Eggersdorfer, M.; Laviano, A.; Rolland, Y.; Smith, A.D.; Warnke, I.; Weimann, A.; Calder, P.C. Expert opinion on benefits of long-chain omega-3 fatty acids (DHA and EPA) in aging and clinical nutrition. Nutrients 2020, 12, 2555. [CrossRef] [PubMed]

24. Sharma, T.; Mandal, C.C. Omega-3 fatty acids in pathological calcification and bone health. J. Food Biochem. 2020, 44, e13333. [CrossRef] [PubMed]

25. Xu, H.; Turchini, G.M.; Francis, D.S.; Liang, M.; Mock, T.S.; Rombenso, A.; Ai, Q. Are fish what they eat? A fatty acid's perspective. Prog. Lipid Res. 2020, 80, 101064. [CrossRef] [PubMed]

26. The World Bank. Fish to 2030: Prospects for Fisheries and Aquaculture; World Bank Report Number 83177-GLB; The World Bank: Washington, DC, USA, 2013.

27. Tocher, D.R.; Betancor, M.B.; Sprague, M.; Olsen, R.E.; Napier, J.A. Omega-3 long-chain polyunsaturated fatty acids, EPA and DHA: Bridging the gap between supply and demand. Nutrients 2019, 11, 89. [CrossRef] [PubMed]

28. Camacho-Rodríguez, J.; Macías-Sánchez, M.D.; Cerón-García, M.; Alarcón, F.J.; Molina-Grima, E. Microalgae as a potential ingredient for partial fish meal replacement in aquafeeds: Nutrient stability under different storage conditions. Environ. Biol. Fishes 2018, 30, 1049-1059. [CrossRef]

29. Dineshbabu, G.; Goswami, G.; Kumar, R.; Sinha, A.; Das, D. Microalgae-Nutritious, sustainable aqua- and animal feed source. J. Funct. Foods 2019, 62, 103545. [CrossRef]

30. Chauton, M.S.; Reitan, K.I.; Norsker, N.H.; Tveterås, R.; Kleivdal, H.T. A techno-economic analysis of industrial production of marine microalgae as a source of EPA and DHA-rich raw material for aquafeed: Research challenges and possibilities. Aquaculture 2015, 436, 95-103. [CrossRef]

31. Turon, V.; Trably, E.; Fayet, A.; Fouilland, E.; Steyer, J.-P. Raw dark fermentation effluent to support heterotrophic microalgae growth: Microalgae successfully outcompete bacteria for acetate. Algal Res. 2015, 12, 119-125. [CrossRef]

32. Turon, V.; Trably, E.; Fouilland, E.; Steyer, J.-P. Potentialities of dark fermentation effluents as substrates for microalgae growth: A review. Process Biochem. 2016, 51, 1843-1854. [CrossRef]

33. Stemmler, K.; Massimi, R.; Kirkwood, A.E. Growth and fatty acid characterization of microalgae isolated from municipal waste-treatment systems and the potential role of algal-associated bacteria in feedstock production. PeerJ 2016, 4, e1780. [CrossRef] [PubMed]

34. Omega 3 Market Size, Trends | Industry Report, 2020-2027, (n.d.). Available online: https://www. grandviewresearch.com/industry-analysis/omega-3-market (accessed on 15 December 2020).

35. Omega-3 Market by Type (DHA, EPA, and ALA), Application (Dietary Supplements, Functional Foods E Beverages, Pharmaceuticals, Infant Formula, and Pet Food E Feed), Source (Marine and Plant), and Region-Global Forecasts to 2025; MarketsandMarkets: Pune, India, 2019.

36. Eurostat. World Population Day: Population Trends Up to 2100. Available online: https://ec.europa.eu/ eurostat/web/products-eurostat-news/-/EDN-20200711-1? inheritRedirect=true\&redirect $=\% 2$ Feurostat $\% 2 \mathrm{~F}$ (accessed on 10 December 2020).

37. McClellan, M.; Brown, N.; Califf, R.M.; Warner, J.J. Call to action: Urgent challenges in cardiovascular disease: A presidential advisory from the American Heart Association. Circulation 2019, 139, e44-e54. [CrossRef] [PubMed]

38. EFSA Panel of Dietetic Products. Scientific opinion on dietary reference values for fats, including saturated fatty acids, polyunsaturated fatty acids, monounsaturated fatty acids, trans fatty acids, and cholesterol. EFSA J. 2010, 8, 1461. [CrossRef]

39. 6th congress of the international society for the study of fatty acids and lipids. Prog. Lipid Res. 2004, 43, 382. [CrossRef]

40. GOED Omega-3. Intake Recommendations. Available online: https://www.goedomega3.com/intakerecommendations (accessed on 8 December 2020). 
41. GOBLEFISH-Information and Analysis on World Fish Trade. A Simple Overview of Omega-3. Available online: http://www.fao.org/in-action/globefish/fishery-information/resource-detail/en/c/1052098/ (accessed on 8 December 2020).

42. ISSFAL. 3. Intake of PUFA in Healthy Adults. Available online: https://www.issfal.org/statement-3 (accessed on 8 December 2020).

43. Winkler, B.S.; Boulton, M.E.; Gottsch, J.D.; Sternberg, P. Oxidative damage and age-related macular degeneration. Mol. Vis. 1999, 5, 32. [PubMed]

44. Mukherjee, P.K.; Marcheselli, V.L.; Serhan, C.N.; Bazan, N.G. From the cover: Neuroprotectin D1: A docosahexaenoic acid-derived docosatriene protects human retinal pigment epithelial cells from oxidative stress. Proc. Natl. Acad. Sci. USA 2004, 101, 8491-8496. [CrossRef]

45. Bernstein, P.S.; Sharifzadeh, M.; Liu, A.; Ermakov, I.; Nelson, K.; Sheng, X.; Panish, C.; Carlstrom, B.; Hoffman, R.O.; Gellermann, W. Blue-light reflectance imaging of macular pigment in infants and children. Investig. Ophthalmol. Vis. Sci. 2013, 54, 4034-4040. [CrossRef]

46. Taylor, H.R.; Munoz, B.; West, S.; Bressler, N.M.; Bressler, S.B.; Rosenthal, F.S. Visible light and risk of age-related macular degeneration. Trans. Am. Ophthalmol. Soc. 1990, 88, 163-178.

47. Johnson, E.J.; Chung, H.-Y.; Caldarella, S.M.; Snodderly, D.M. The influence of supplemental lutein and docosahexaenoic acid on serum, lipoproteins, and macular pigmentation. Am. J. Clin. Nutr. 2008, 87, 1521-1529. [CrossRef]

48. EFSA Dietetic Products, Nutrition, and Allergies (NDA). Scientific opinion on health benefits of seafood (fish and shellfish) consumption in relation to health risks associated with exposure to methylmercury. EFSA J. 2014, 12, 3761. [CrossRef]

49. Deutschen Gesellschaft für Ernährung e.V. Logoübergabe: Mehr Qualität beim Essen. Available online: www.dge.de (accessed on 10 December 2020).

50. World Health Organization. Diet, Nutrition and the Prevention of Chronic Diseases; WHO Technical Report Series 916; WHO: Geneva, Switzerland, 2003.

51. Organisation for Economic Co-operation and Development. OECD-FAO Agricultural Outlook 2019-2028. In OECD Agriculture Statistics; OECD: Paris, France, 2019.

52. OECD-FAO Agricultural Outlook 2020-2029. Available online: https://www.oecd-ilibrary.org/agricultureand-food/data/oecd-agriculture-statistics_agr-data-en (accessed on 16 July 2019).

53. OECD-FAO Agricultural Outlook 2019-2028. Available online: https://stats.oecd.org/Index.aspx? DataSetCode=HIGH_AGLINK_2019 (accessed on 1 August 2019).

54. Sprague, M.; Dick, J.R.; Tocher, D.R. Impact of sustainable feeds on omega-3 long-chain fatty acid levels in farmed Atlantic salmon, 2006-2015. Sci. Rep. 2016, 6, 21892. [CrossRef]

55. Global Salmon Initiative. Available online: https://globalsalmoninitiative.org/es/ (accessed on 12 November 2020).

56. Kiron, V.; Phromkunthong, W.; Huntley, M.; Archibald, I.; De Scheemaker, G. Marine microalgae from biorefinery as a potential feed protein source for Atlantic salmon, common carp and whiteleg shrimp. Aquac. Nutr. 2012, 18, 521-531. [CrossRef]

57. Patnaik, S.; Samocha, T.M.; Davis, D.A.; Bullis, R.A.; Browdy, C.L. The use of HUFA-rich algal meals in diets for Litopenaeus vannamei. Aquac. Nutr. 2006, 12, 395-401. [CrossRef]

58. Kousoulaki, K.; Saether, B.-S.; Albrektsen, S.; Noble, C.; Sæther, B. Review on European sea bass (Dicentrarchus labrax, Linnaeus, 1758) nutrition and feed management: A practical guide for optimizing feed formulation and farming protocols. Aquac. Nutr. 2015, 21, 129-151. [CrossRef]

59. Santigosa, E.; Constant, D.; Prudence, D.; Wahli, T.; Verlhac-Trichet, V. A novel marine algal oil containing both EPA and DHA is an effective source of omega-3 fatty acids for rainbow trout (Oncorhynchus mykiss). J. World Aquac. Soc. 2020, 51, 649-665. [CrossRef]

60. Betancor, M.B.; Sprague, M.; Sayanova, O.; Usher, S.; Metochis, C.; Campbell, P.J.; Napier, J.A.; Tocher, D.R. Nutritional evaluation of an EPA-DHA oil from transgenic Camelina sativa in feeds for post-smolt Atlantic salmon (Salmo salar L.). PLoS ONE 2016, 11, e0159934. [CrossRef]

61. Betancor, M.B.; Sprague, M.; Montero, D.; Usher, S.; Sayanova, O.; Campbell, P.; Napier, J.A.; Caballero, M.J.; Izquierdo, M.S.; Tocher, D.R. Replacement of marine fish oil with de novo omega-3 Oils from transgenic Camelina sativa in feeds for gilthead sea bream (Sparus aurata L.). Lipids 2016, 51, 1171-1191. [CrossRef] 
62. Betancor, M.B.; Sprague, M.; Sayanova, O.; Usher, S.; Campbell, P.; Napier, J.A.; Caballero, M.; Tocher, D.R. Evaluation of a high-EPA oil from transgenic Camelina sativa in feeds for Atlantic salmon (Salmo salar L.): Effects on tissue fatty acid composition, histology and gene expression. Aquaculture 2015, 444, 1-12. [CrossRef]

63. Ruyter, B.; Sissener, N.H.; Østbye, T.-K.; Simon, C.J.; Krasnov, A.; Bou, M.; Sanden, M.; Nichols, P.D.; Lutfi, E.; Berge, G.M. n-3 Canola oil effectively replaces fish oil as a new safe dietary source of DHA in feed for juvenile Atlantic salmon. Br. J. Nutr. 2019, 122, 1329-1345. [CrossRef]

64. Guschina, I.A.; Harwood, J.L. Lipids and lipid metabolism in eukaryotic algae. Prog. Lipid Res. 2006, 45, 160-186. [CrossRef] [PubMed]

65. Renaud, S.M.; Thinh, L.-V.; Lambrinidis, G.; Parry, D.L. Effect of temperature on growth, chemical composition and fatty acid composition of tropical Australian microalgae grown in batch cultures. Aquaculture 2002, 211, 195-214. [CrossRef]

66. Ackman, R.G.; Tocher, C.S.; McLachlan, J. Marine phytoplankter fatty acids. J. Fish. Res. Board Can. 1968, 25, 1603-1620. [CrossRef]

67. Hixson, S.M.; Arts, M.T. Climate warming is predicted to reduce omega-3, long-chain, polyunsaturated fatty acid production in phytoplankton. Glob. Chang. Biol. 2016, 22, 2744-2755. [CrossRef]

68. Colombo, S.M.; Rodgers, T.F.M.; Diamond, M.L.; Bazinet, R.P.; Arts, M.T. Projected declines in global DHA availability for human consumption as a result of global warming. Ambio 2020, 49, 865-880. [CrossRef] [PubMed]

69. Seong, T.; Matsutani, H.; Haga, Y.; Kitagima, R.; Satoh, S. First step of non-fish meal, non-fish oil diet development for red seabream, (Pagrus major), with plant protein sources and microalgae Schizochytrium sp. Aquac. Res. 2019, 50, 2460-2468. [CrossRef]

70. Ward, O.P.; Singh, A. Omega-3/6 fatty acids: Alternative sources of production. Process Biochem. 2005, 40, 3627-3652. [CrossRef]

71. Bernaerts, T.M.; Gheysen, L.; Kyomugasho, C.; Kermani, Z.J.; Vandionant, S.; Foubert, I.; Hendrickx, M.E.; Van Loey, A.M. Comparison of microalgal biomasses as functional food ingredients: Focus on the composition of cell wall related polysaccharides. Algal Res. 2018, 32, 150-161. [CrossRef]

72. Ma, Y.; Wang, Z.; Yu, C.; Yin, Y.; Zhou, G. Evaluation of the potential of 9 Nannochloropsis strains for biodiesel production. Bioresour. Technol. 2014, 167, 503-509. [CrossRef]

73. Ryckebosch, E.; Bruneel, C.; Termote-Verhalle, R.; Goiris, K.; Muylaert, K.; Foubert, I. Nutritional evaluation of microalgae oils rich in omega-3 long chain polyunsaturated fatty acids as an alternative for fish oil. Food Chem. 2014, 160, 393-400. [CrossRef]

74. Hamilton, M.L.; Warwick, J.; Terry, A.; Allen, M.J.; Napier, J.A.; Sayanova, O. Towards the industrial production of omega-3 long chain polyunsaturated fatty acids from a genetically modified diatom Phaeodactylum tricornutum. PLoS ONE 2015, 10, e0144054. [CrossRef] [PubMed]

75. Fu, W.; Nelson, D.R.; Mystikou, A.; Daakour, S.; Salehi-Ashtiani, K. Advances in microalgal research and engineering development. Curr. Opin. Biotechnol. 2019, 59, 157-164. [CrossRef] [PubMed]

76. Rastogi, A.; Maheswari, U.; Dorrell, R.G.; Vieira, F.R.J.; Maumus, F.; Kustka, A.; McCarthy, J.; Allen, A.E.; Kersey, P.; Bowler, C.; et al. Integrative analysis of large scale transcriptome data draws a comprehensive landscape of Phaeodactylum tricornutum genome and evolutionary origin of diatoms. Sci. Rep. 2018, 8, 1-14. [CrossRef] [PubMed]

77. Leu, S.; Boussiba, S. Advances in the production of high-value products by microalgae. Ind. Biotechnol. 2014, 10, 169-183. [CrossRef]

78. Moomaw, W.R.; Berzin, I.; Tzachor, A. Cutting out the middle fish: Marine microalgae as the next sustainable omega-3 fatty acids and protein source. Ind. Biotechnol. 2017, 13, 234-243. [CrossRef]

79. Cui, Y.; Thomas-Hall, S.R.; Schenk, P.M. Phaeodactylum tricornutum microalgae as a rich source of omega-3 oil: Progress in lipid induction techniques towards industry adoption. Food Chem. 2019, 297, 124937. [CrossRef]

80. Barclay, W.R.; Meager, K.M.; Abril, J.R. Heterotrophic production of long chain omega-3 fatty acids utilizing algae and algae-like microorganisms. Environ. Biol. Fishes 1994, 6, 123-129. [CrossRef]

81. Byreddy, A.R. Thraustochytrids as an alternative source of omega-3 fatty acids, carotenoids and enzymes. Lipid Technol. 2016, 28, 68-70. [CrossRef]

82. Gupta, A.; Barrow, C.J.; Puri, M. Omega-3 biotechnology: Thraustochytrids as a novel source of omega-3 oils. Biotechnol. Adv. 2012, 30, 1733-1745. [CrossRef] 
83. Chang, K.J.L.; Nichols, C.M.; Blackburn, S.I.; Dunstan, G.A.; Koutoulis, A.; Nichols, P.D. Comparison of Thraustochytrids Aurantiochytrium sp., Schizochytrium sp., Thraustochytrium sp., and Ulkenia sp. for production of biodiesel, long-chain omega-3 oils, and exopolysaccharide. Mar. Biotechnol. 2014, 16, 396-411. [CrossRef]

84. Chalima, A.; Oliver, L.; de Castro, L.F.; Karnaouri, A.; Dietrich, T.; Topakas, E. Utilization of volatile fatty acids from microalgae for the production of high added value compounds. Fermentation 2017, 3, 54. [CrossRef]

85. Prokop, A.; Bajpai, R.K.; Zappi, M.E. (Eds.) Algal Biorefineries; Springer: Cham, Switzerland, 2015; Volume 2. [CrossRef]

86. Espinosa-Gonzalez, I.; Parashar, A.; Bressler, D.C. Heterotrophic growth and lipid accumulation of Chlorella protothecoides in whey permeate, a dairy by-product stream, for biofuel production. Bioresour. Technol. 2014, 155, 170-176. [CrossRef] [PubMed]

87. Pleissner, D.; Lam, W.C.; Sun, Z.; Lin, C.S.K. Food waste as nutrient source in heterotrophic microalgae cultivation. Bioresour. Technol. 2013, 137, 139-146. [CrossRef] [PubMed]

88. Pleissner, D.; Rumpold, B.A. Utilization of organic residues using heterotrophic microalgae and insects. Waste Manag. 2018, 72, 227-239. [CrossRef]

89. Wang, Q.; Ye, H.; Sen, B.; Xie, Y.; He, Y.; Park, S.; Wang, G. Improved production of docosahexaenoic acid in batch fermentation by newly-isolated strains of Schizochytrium sp. and Thraustochytriidae sp. through bioprocess optimization. Synth. Syst. Biotechnol. 2018, 3, 121-129. [CrossRef]

90. Thom, L.T.; Ha, N.C.; Hong, D.D. Extraction of bio-oil rich in omega 3-6 fatty acid using different methods from heterotrophic marine microalga Schizochytrium mangrovei. TAP CHI SINH HOC 2017, 39, 359-366. [CrossRef]

91. Brennan, L.; Owende, P. Biofuels from microalgae-A review of technologies for production, processing, and extractions of biofuels and co-products. Renew. Sustain. Energy Rev. 2010, 14, 557-577. [CrossRef]

92. Nguyen, H.C.; Su, C.; Yu, Y.-K.; Huong, D.T.M. Sugarcane bagasse as a novel carbon source for heterotrophic cultivation of oleaginous microalga Schizochytrium sp. Ind. Crop. Prod. 2018, 121, 99-105. [CrossRef]

93. Yin, F.-W.; Zhu, S.-Y.; Guo, D.-S.; Ren, L.-J.; Ji, X.-J.; Huang, H.; Gao, Z. Development of a strategy for the production of docosahexaenoic acid by Schizochytrium sp. from cane molasses and algae-residue. Bioresour. Technol. 2019, 271, 118-124. [CrossRef]

94. Abou-Shanab, R.A.I.; Kim, S.; Ji, M.-K.; Lee, S.-H.; Roh, H.-S.; Jeon, B.-H. Municipal wastewater utilization for biomass and biodiesel production by Scenedesmus obliquus HM103382 and Micractinium reisseri JN169781. J. Renew. Sustain. Energy 2013, 5, 052006. [CrossRef]

95. Luangpipat, T.; Chisti, Y. Biomass and oil production by Chlorella vulgaris and four other microalgae-Effects of salinity and other factors. J. Biotechnol. 2017, 257, 47-57. [CrossRef] [PubMed]

96. Karnaouri, A.; Chalima, A.; Kalogiannis, K.G.; Varamogianni-Mamatsi, D.; Lappas, A.; Topakas, E. Utilization of lignocellulosic biomass towards the production of omega-3 fatty acids by the heterotrophic marine microalga Crypthecodinium cohnii. Bioresour. Technol. 2020, 303, 122899. [CrossRef] [PubMed]

97. Paz, A.; Karnaouri, A.; Templis, C.C.; Papayannakos, N.; Topakas, E. Valorization of exhausted olive pomace for the production of omega-3 fatty acids by Crypthecodinium cohnii. Waste Manag. 2020, 118, 435-444. [CrossRef]

98. Lage, S.; Kudahettige, N.P.; Ferro, L.; Matsakas, L.; Funk, C.; Rova, U.; Gentili, F.G. Microalgae cultivation for the biotransformation of birch wood hydrolysate and dairy effluent. Catalysts 2019, 9, 150. [CrossRef]

99. Lee, W.S.; Chua, A.S.M.; Yeoh, H.K.; Ngoh, G.C. A review of the production and applications of waste-derived volatile fatty acids. Chem. Eng. J. 2014, 235, 83-99. [CrossRef]

100. Singhania, R.R.; Patel, A.K.; Christophe, G.; Fontanille, P.; Larroche, C. Biological upgrading of volatile fatty acids, key intermediates for the valorization of biowaste through dark anaerobic fermentation. Bioresour. Technol. 2013, 145, 166-174. [CrossRef]

101. European Committee for Standardization. CEN/WS EvaVOLATILE-Anaerobic Digestion Plants-Feasibility As-Sessment Methodology for Integrating a Volatile Fatty Acid Platform Technology. Available online: https://standards.cen.eu/dyn/www/f?p=204:110:0::::FSP_PROJECT,FSP_ORG_ID:70814,2686036\& cs=181510A05E65E441FB27025E52B52E3C4 (accessed on 11 December 2020).

102. Chalima, A.; Hatzidaki, A.; Karnaouri, A.; Topakas, E. Integration of a dark fermentation effluent in a microalgal-based biorefinery for the production of high-added value omega-3 fatty acids. Appl. Energy 2019, 241, 130-138. [CrossRef] 
103. Chalima, A.; Taxeidis, G.; Topakas, E. Optimization of the production of docosahexaenoic fatty acid by the heterotrophic microalga Crypthecodinium cohnii utilizing a dark fermentation effluent. Renew. Energy 2020, 152, 102-109. [CrossRef]

104. Esteban-Gutiérrez, M.; Garcia-Aguirre, J.; Irizar, I.; Aymerich, E. From sewage sludge and agri-food waste to VFA: Individual acid production potential and up-scaling. Waste Manag. 2018, 77, 203-212. [CrossRef]

105. Turon, V.; Trably, E.; Fouilland, E.; Steyer, J.-P. Growth of Chlorella sorokiniana on a mixture of volatile fatty acids: The effects of light and temperature. Bioresour. Technol. 2015, 198, 852-860. [CrossRef]

106. Patel, A.; Rova, U.; Christakopoulos, P.; Matsakas, L. Simultaneous production of DHA and squalene from Aurantiochytrium sp. grown on forest biomass hydrolysates. Biotechnol. Biofuels 2019, 12, 255. [CrossRef] [PubMed]

107. Patel, A.; Rova, U.; Christakopoulos, P.; Matsakas, L. Assessment of fatty acids profile and omega-3 polyunsaturated fatty acid production by the oleaginous marine thraustochytrid Aurantiochytrium sp. T66 cultivated on volatile fatty acids. Biomolecules 2020, 10, 694. [CrossRef] [PubMed]

108. Turon, V.; Baroukh, C.; Trably, E.; Latrille, E.; Fouilland, E.; Steyer, J.-P. Use of fermentative metabolites for heterotrophic microalgae growth: Yields and kinetics. Bioresour. Technol. 2015, 175, 342-349. [CrossRef] [PubMed]

109. Liu, H.; Wang, L.; Zhang, X.; Fu, B.; Liu, H.; Li, Y.; Lu, X. A viable approach for commercial VFAs production from sludge: Liquid fermentation in anaerobic dynamic membrane reactor. J. Hazard. Mater. 2019, 365, 912-920. [CrossRef]

Publisher's Note: MDPI stays neutral with regard to jurisdictional claims in published maps and institutional affiliations. 